\title{
Indicators of Lipid Peroxidation Reactions and State of Structural Tissues of the Dentition System in Wistar Rats under Various Stress Regimes
}

\author{
Marina A. Darenskaya, PhD, ScD*; Larisa R. Kolesnikova, PhD; Lyubov V. Rychkova, \\ $\mathrm{PhD}$, ScD; Lyudmila A. Grebenkina, PhD, ScD; Natalya V. Semenova, PhD, ScD; Sergey I. \\ Kolesnikov, Academician of the RAS; Lyubov I. Kolesnikova, Academician of the RAS \\ Scientific Centre for Family Health and Human Reproduction Problems \\ Irkutsk, the Russian Federation
}

\begin{abstract}
The aim of this research was to investigate the content of lipid peroxidation (LPO) products and components of antioxidant defense (AOD), as well as to evaluate morphometric parameters of the dentition system tissues in Wistar rats when modeling acute and chronic modes of immobilization stress.

Methods and Results: The work was performed on young (2.5-3 months), sexually mature male rats of the Wistar line, weighing 200-220g. The design of the study consisted in evaluating biochemical and morphometric parameters at the stage before immobilization - intact animals (10 rats) - as well as in modeling various stress modes: acute stress (3 hours from the moment of 3-hour single immobilization) and chronic stress (1-hour immobilization with an interval of 72 hours between separate stress episodes on Days 1, 5, 9 and 13). Both modes included 20 rats. The intensity of lipid peroxidation-antioxidant defense processes was assessed using spectrophotometric and fluorometric methods. The microscopic and morphometric studies were performed in the light-optical microscope AxioScope A1 and included a detailed description of all changes in the tooth and periodontal tissues. We found that acute stress is accompanied by increased LPO reactions at the stage of primary and secondary products with simultaneous activation of antioxidant factors. In chronic stress exposure, there is an accumulation of thiobarbituric acid reactants, with a decrease in the level of non-enzymatic components - $\alpha$-tocopherol, retinol, and oxidized glutathione. The changes in the state of the dentition system in Wistar rats was accompanied by an increase in the area of the microcirculatory bed of the periodontium and pulp and a natural reduction in the connective tissue area, with an increase in the thickness of vascular endothelium and an increased number of cellular elements that control metabolic processes, especially pronounced in acute stress. The change in the mode of stress exposure to chronic in animals of this line was characterized by generally similar changes with reduced reaction intensity.
\end{abstract}

Conclusion: The processes of LPO-AOD and the indicators of the dentition system in Wistar rats undergo changes depending on the mode of stress exposure. (International Journal of Biomedicine. 2020;10(2):142-147.)

Key Words: Wistar rats $\bullet$ lipid peroxidation $\bullet$ periodontium $\bullet$ pulp $\bullet$ acute stress $\bullet$ chronic stress

\section{Abbreviations}

AS, acute stress; AOD, antioxidant defense; CD, conjugated dienes; ChS, chronic stress; CT, connective tissue; DB, double bonds; GSH, reduced glutathione; GSSG, oxidized glutathione; KD-CT, ketodienes and conjugated trienes; LPO, lipid peroxidation; SOD, superoxide dismutase; TAA, total antioxidant activity; TBARs, thiobarbituric acid reactants.

\section{Introduction}

It has been established that the impact of stress factors is one of the most important causes that provoke the development of various diseases. ${ }^{(1,2)}$ Diseases of the dentition system tissues are the most common pathologies in the population, and stress plays a significant role in their pathogenesis. ${ }^{(3)}$ The views in the existing literature on the primary effect of stress on the body (the so-called AS) suggest that a typical stress reaction ensures maintenance of homeostatic reactions of the body in 
the conditions completely new for it. ${ }^{(4)}$ This reaction is based on a set of stress-implementing and stress-limiting systems. The latter include an AOD system that limits the action of stressors at the cellular level. ${ }^{(5-7)}$ The primary mediators of the stress response are LPO processes, which initiate the damaging effect of various factors, including at the level of the central links of neuroendocrine regulation. ${ }^{(8)}$

Among the cognition methods that are of significant scientific and practical interest, an important place is occupied by pathological processes modeling, which allows theoretically generalizing an array of data that are not explained by existing concepts of biology and medicine. ${ }^{(9-11)}$ It has been established that when using immobilization as a model of stress exposure, there are changes characteristic of psychoemotional stress, invariably accompanied by activation of the sympathoadrenal system, as well as numerous transformations in the blood system. ${ }^{(12)}$ The simplicity of the method, the standardness of changes, and the absence of additional damaging factors make immobilization the most appropriate model for stress exposure $^{(13)}$ It has been found that the systemic response of the tissues of the dentition system in rats is generally similar to that of humans, which makes these animals a promising object for studying the pathogenesis of various odontogenic disorders. It is also currently known that immobilization stress has numerous damaging effects on periodontal tissue, consisting in development of degenerative changes in the $\mathrm{CT}$ of the gums, reducing its osteotaryngeal base, epithelium peeling, osteoporosis development, etc. ${ }^{(14)}$

In this regard, it is extremely interesting to study systemic non-specific changes (LPO system), as well as the state of the morphological picture of the dentition system tissues, and their interactions in animals when modeling various modes of immobilization stress.

The aim of this research was to investigate the content of LPO products and components of AOD, as well as to evaluate morphometric parameters of the dentition system tissues in Wistar rats when modeling acute and chronic modes of immobilization stress.

\section{Materials and Methods}

The work was performed on young (2.5-3 months), sexually mature male rats of the Wistar line, weighing 200$220 \mathrm{~g}$. The animals were bred at the SPF-vivarium Center for collective use of the Federal research center "Institute of Cytology and Genetics," Siberian branch of RAS (Novosibirsk). The design of the study consisted in evaluating biochemical and morphometric parameters at the stage before immobilization - intact animals (10 rats) - as well as in modeling various stress modes: AS (3 hours from the moment of 3-hour single immobilization) and ChS (1-hour immobilization with an interval of 72 hours between separate stress episodes on Days 1, 5, 9 and 13). ${ }^{(15)}$ Both modes included 20 rats. Three-hour single immobilization of the animal on its back was performed by rigid fixation of the limbs. ${ }^{(15,16)}$

The intensity of LPO processes was evaluated based on the content of substrates with unsaturated DB: CD and KD-CT.(17) The content of TBARs was determined fluorimetrically. ${ }^{(18)}$ The state of the AOD system ${ }^{(19)}$ was determined by TAA of the blood, according to the content of TAA components: $\alpha$-tocopherol and retinol, ${ }^{(20)}$ the SOD activity, ${ }^{(21)}$ and the content of GSH and GSSG. ${ }^{(22)}$ Measurements were performed on the Shimadzu RF1501 spectrophotometer (Japan) and the Shimadzu RF-1650 spectrophotometer (Japan).

To study the state of the dentition system after euthenizing the animals, pieces of the lower and upper jaw with incisors and molars were taken and fixed in a neutral $10 \%$ solution of formalin. Tissue fragments were decalcified in a 5\% solution of nitric acid for 3 to 5 days. The material was processed in a Sacura, Japan, vacuum processing machine. Filling in the modular paraffin was done by the Tissue-Tek ${ }^{\circledR}$ TEC ${ }^{\text {TM }} 5$ filling system (Sacura, Japan). Cutting standard serial sections with a thickness of 5 microns was performed on semi-automatic rotary microtomes CM-502 (Microm, Germany) using disposable knives of the Sacura company. The sections were manually stained on slides and covered with cover glass; they were stained with hematoxylin and eosin, and picro-fuchsin using the van Gieson method to identify CT fibers. The microscopic and morphometric studies were performed in the light-optical microscope AxioScope A1 (Carl Zeiss, Germany) at $\times 40$, $\times 100, \times 400$, and $\times 600$ magnification and included a detailed description of all changes in the tooth and periodontal tissues. Changes in the pulp and periodontal vessels (vascular lumen state, blood filling, endothelial condition) were described in detail, and changes in the pulp and periodontal tissues, as well as the state of odontoblasts, were assessed.

The dentition system was assessed using a number of quantitative criteria of the periodontium and pulp-the area (in \%) of periodontal and pulp vessels, the area (in \%) of periodontal and pulp CT, the thickness of the periodontal and pulp vascular endothelium $\left(\mu \mathrm{m}^{2}\right)$, and the total number of fibroblasts and odontoblasts in the field of view.

Work on the animals was done in compliance with the principles of the Helsinki Declaration on the humane treatment of animals, stated in normative documents of the European community(86/609/EU), "Rules of works using experimental animals" (order of MH of the USSR № 775 dated 12.08.1977), Manual on Experimental (Preclinical) Study of New Pharmacological Substances, ${ }^{(23)}$ and "Good laboratory practice" (MHRF Order No. 708H dated 23.08.2010).

Statistical analysis was performed using the Statistica 6.1 software package (Stat-Soft Inc., USA). The normality of distribution of continuous variables was tested by the Kolmogorov-Smirnov test with the Lilliefors correction and Shapiro-Wilk test. For descriptive analysis, results are presented as mean \pm standard deviation (SD), median (Me), interquartile range (IQR; 25th to 75th percentiles). Differences of continuous variables departing from the normal distribution, even after transformation, were tested by the Mann-Whitney U-test. A probability value of $P \leq 0.05$ was considered statistically significant.

\section{Results and Discussion}

When modeling the AS mode in Wistar rats, unidirectional changes were observed at all stages of formation 
of LPO products in the form of an increase in the values of $\mathrm{CD}(P=0.0429)$, KD-CT $(P<0.0001)$ and TBARs $(P=0.0012)$, relative to the intact animals (Table 1). Changes in the AOD system under the same mode were related to a decrease in the level of TAA $(P=0.0208)$, an increase in the SOD activity $(P<0.0001)$, and the retinol content $(P<0.0001)$ (Table 1$)$. The glutathione metabolism indicators in the AS mode also significantly changed - in the form of an increase in GSH values $(P=0.0031)$.

Table 1.

The level of $L P O$ products and components of the AOD system in Wistar rats under various stress modes (Me, IQR $\left.\left[P_{25} ; P_{75}\right]\right)$

\begin{tabular}{|c|c|c|c|c|}
\hline Parameters & $\begin{array}{c}\text { Intact animals } \\
\text { (1) }\end{array}$ & $\begin{array}{l}\text { AS mode } \\
\text { (2) }\end{array}$ & $\begin{array}{c}\text { ChS mode } \\
\text { (3) }\end{array}$ & $\begin{array}{c}\text { Statistical } \\
\text { significance } \\
\text { of } P \leq 0.05\end{array}$ \\
\hline $\begin{array}{l}\text { DB, } \\
\text { standard units }\end{array}$ & $\begin{array}{c}1.81 \\
1.54-1.87\end{array}$ & $\begin{array}{c}1.66 \\
1.45-1.80\end{array}$ & $\begin{array}{c}1.82 \\
1.78-1.86\end{array}$ & $\mathrm{P}_{2}-\mathrm{P}_{3}$ \\
\hline $\mathrm{CD}, \mu \mathrm{mol} / 1$ & $\begin{array}{c}0.86 \\
0.73-0.89\end{array}$ & $\begin{array}{c}1.30 \\
0.99-1.37\end{array}$ & $\begin{array}{c}0.86 \\
0.78-0.88\end{array}$ & $\begin{array}{l}\mathrm{P}_{1}-\mathrm{P}_{2} \\
\mathrm{P}_{2}-\mathrm{P}_{3}\end{array}$ \\
\hline $\begin{array}{l}\text { KD-CT, } \\
\text { standard units }\end{array}$ & $\begin{array}{c}0.34 \\
0.31-0.37\end{array}$ & $\begin{array}{c}0.66 \\
0.56-0.68\end{array}$ & $\begin{array}{c}0.46 \\
0.44-0.52\end{array}$ & $\begin{array}{l}\mathrm{P}_{1}-\mathrm{P}_{2} \\
\mathrm{P}_{1}-\mathrm{P}_{3} \\
\mathrm{P}_{2}-\mathrm{P}_{3}\end{array}$ \\
\hline $\begin{array}{l}\text { TBARs, } \\
\mu \mathrm{mol} / 1\end{array}$ & $\begin{array}{c}0.79 \\
0.78-0.94\end{array}$ & $\begin{array}{c}1.03 \\
0.96-1.16\end{array}$ & $\begin{array}{c}1.47 \\
1.25-1.83\end{array}$ & $\begin{array}{l}\mathrm{P}_{1}-\mathrm{P}_{2} \\
\mathrm{P}_{2}-\mathrm{P}_{3} \\
\mathrm{P}_{1}^{2}-\mathrm{P}_{3}\end{array}$ \\
\hline $\begin{array}{l}\text { TAA, } \\
\text { standard units }\end{array}$ & $\begin{array}{c}17.14 \\
14.36-18.90 \\
\end{array}$ & $\begin{array}{c}13.65 \\
11.36-14.41 \\
\end{array}$ & $\begin{array}{c}12.34 \\
9.08-2.97 \\
\end{array}$ & $\begin{array}{l}\mathrm{P}_{1}-\mathrm{P}_{2} \\
\mathrm{P}_{1}-\mathrm{P}_{3}\end{array}$ \\
\hline $\begin{array}{l}\text { SOD activity, } \\
\text { standard units }\end{array}$ & $\begin{array}{c}1.98 \\
1.94-2.14\end{array}$ & $\begin{array}{c}2.62 \\
2.53-2.77\end{array}$ & $\begin{array}{c}2.96 \\
2.76-3.07\end{array}$ & $\begin{array}{l}\mathrm{P}_{1}-\mathrm{P}_{2} \\
\mathrm{P}_{1}-\mathrm{P}_{3}\end{array}$ \\
\hline $\begin{array}{l}\alpha \text {-tocopherol, } \\
\mu \mathrm{mol} / 1\end{array}$ & $\begin{array}{c}11.20 \\
9.85-12.30 \\
\end{array}$ & $\begin{array}{c}9.23 \\
9.04-11.13 \\
\end{array}$ & $\begin{array}{c}5.76 \\
3.49-5.88 \\
\end{array}$ & $\begin{array}{l}\mathrm{P}_{2}-\mathrm{P}_{3} \\
\mathrm{P}_{1}^{2}-\mathrm{P}_{3}\end{array}$ \\
\hline $\begin{array}{l}\text { Retinol, } \\
\mu \mathrm{mol} / 1\end{array}$ & $\begin{array}{c}0.51 \\
0.48-0.65 \\
\end{array}$ & $\begin{array}{c}0.95 \\
0.86-1.08 \\
\end{array}$ & $\begin{array}{c}0.52 \\
0.51-0.53 \\
\end{array}$ & $\begin{array}{l}\mathrm{P}_{1}-\mathrm{P}_{2} \\
\mathrm{P}_{2}-\mathrm{P}_{3}\end{array}$ \\
\hline $\begin{array}{l}\mathrm{GSH}, \\
\mathrm{mmol} / \mathrm{l}\end{array}$ & $\begin{array}{c}1.98 \\
1.89-2.09\end{array}$ & $\begin{array}{c}2.35 \\
2.27-2.41\end{array}$ & $\begin{array}{c}2.26 \\
2.11-2.28 \\
\end{array}$ & $\mathrm{P}_{1}-\mathrm{P}_{2}$ \\
\hline $\begin{array}{l}\text { GSSG, } \\
\mathrm{mmol} / 1\end{array}$ & $\begin{array}{c}2.04 \\
2.00-2.23\end{array}$ & $\begin{array}{c}2.29 \\
2.25-2.32\end{array}$ & $\begin{array}{c}2.04 \\
1.78-2.09\end{array}$ & $\mathrm{P}_{2}-\mathrm{P}_{3}$ \\
\hline
\end{tabular}

The ChS mode was characterized by a significant increase in the levels of KD-CT $(P<0.0001)$ and TBARs $(P<0.0001)$, in comparison with intact rats. The $\mathrm{ChC}$ mode was characterized by a lower level of TAA ( $P=0.0003)$, an increased SOD activity $(P<0.0001)$, and a reduced level of $\alpha$-tocopherol $(P<0.0001)$, in comparison with the baseline level.

In addition, there were statistically significant differences in the studied indicators between stress modes. Thus, the DB level was characterized by the lowest values in AS $(P=0.0337)$, while the content of $\mathrm{CD}$ and $\mathrm{KD}-\mathrm{CT}$ was characterized by higher values in this mode, and the level of TBARs was reduced. Elevated levels of $\alpha$-tocopherol $(P=0.0009)$, retinol $(P<0.0001)$, and GSSG $(P=0.0002)$ were reported in the AOD system for AS compared to ChS.

Morphological changes in the dentition system tissues in Wistar rats by using the AS model related to an increase in the area of the periodontal blood vessels $(P<0.0001)$, a decrease in the area of the periodontal CT $(P<0.0001)$, increased area of the pulp blood vessels $(P<0.0001)$, due to lower values of the pulp CT $(P<0.0001)$ in comparison with intact animals (Table 2). The wall thickness of the periodontal and pulp endothelium increased significantly under AS $(P<0.0001$ in both cases $)$ (Table 2). The number of fibroblasts in the field of view of Wistar rats also increased in this mode $(P=0.0206)$.

Table 2.

Morphological changes in the dentition system tissues in Wistar rats under various stress modes (M $\left.\pm S D, M e, I Q R ~\left[P_{25} ; P_{75}\right]\right)$

\begin{tabular}{|c|c|c|c|c|}
\hline Parameters & $\begin{array}{l}\text { IA } \\
(1)\end{array}$ & $\begin{array}{l}\text { AS mode } \\
\text { (2) }\end{array}$ & $\begin{array}{c}\text { ChS mode } \\
(3)\end{array}$ & \begin{tabular}{|c} 
Statistical \\
significance \\
of $P \leq 0.05$
\end{tabular} \\
\hline $\begin{array}{l}\text { Vessels, } \\
\text { Periodontium, } \\
\%\end{array}$ & $\begin{array}{c}22.78 \pm 2.4 \\
23.05 \\
20.00-24.90\end{array}$ & \begin{tabular}{|c|}
$34.79 \pm 3.7$ \\
34.80 \\
$31.90-38.00$
\end{tabular} & \begin{tabular}{|c|}
$26.53 \pm 3.51$ \\
26.65 \\
$24.00-29.60$
\end{tabular} & $\begin{array}{l}\mathrm{P}_{1}-\mathrm{P}_{2} \\
\mathrm{P}_{1}-\mathrm{P}_{3} \\
\mathrm{P}_{2}-\mathrm{P}_{3}\end{array}$ \\
\hline $\begin{array}{l}\text { CT, } \\
\text { Periodontium, } \\
\%\end{array}$ & $\begin{array}{c}77.22 \pm 2.4 \\
76.95 \\
75.10-80.00\end{array}$ & $\begin{array}{c}65.21 \pm 3.7 \\
65.20 \\
62.00-68.10\end{array}$ & $\begin{array}{c}73.47 \pm 3.51 \\
73.35 \\
70.40-76.00\end{array}$ & $\begin{array}{l}\mathrm{P}_{1}-\mathrm{P}_{2} \\
\mathrm{P}_{2}-\mathrm{P}_{3}\end{array}$ \\
\hline $\begin{array}{l}\text { Vessels, Pulp, } \\
\%\end{array}$ & $\begin{array}{c}23.12 \pm 2.2 \\
22.40 \\
21.20-25.20\end{array}$ & $\begin{array}{c}44.16 \pm 7.2 \\
43.20 \\
40.00-49.60\end{array}$ & $\begin{array}{c}27.28 \pm 3.90 \\
26.40 \\
24.40-29.60\end{array}$ & $\begin{array}{l}\mathrm{P}_{1}-\mathrm{P}_{2} \\
\mathrm{P}_{1}-\mathrm{P}_{3} \\
\mathrm{P}_{2}-\mathrm{P}_{3}\end{array}$ \\
\hline $\begin{array}{l}\text { CT, Pulp, } \\
\%\end{array}$ & $\begin{array}{c}76.88 \pm 2.2 \\
77.00 \\
74.80-78.80 \\
\end{array}$ & $\begin{array}{c}55.84 \pm 7.2 \\
56.80 \\
50.40-60.00\end{array}$ & $\begin{array}{c}72.72 \pm 3.90 \\
73.60 \\
72.00-75.60\end{array}$ & $\begin{array}{l}\mathrm{P}_{1}-\mathrm{P}_{2} \\
\mathrm{P}_{2}-\mathrm{P}_{3}\end{array}$ \\
\hline $\begin{array}{l}\text { VE, } \\
\text { Periodontium, } \\
\mu \mathrm{m}\end{array}$ & $\begin{array}{c}1.17 \pm 0.42 \\
1.19 \\
0.82-1.28\end{array}$ & $\begin{array}{c}4.41 \pm 0.74 \\
4.45 \\
3.91-5.16\end{array}$ & $\begin{array}{c}2.23 \pm 0.45 \\
2.22 \\
1.86-2.28\end{array}$ & $\begin{array}{l}\mathrm{P}_{1}-\mathrm{P}_{2} \\
\mathrm{P}_{1}-\mathrm{P}_{3} \\
\mathrm{P}_{2}-\mathrm{P}_{3}\end{array}$ \\
\hline $\begin{array}{l}\text { VE, } \\
\text { Pulp, } \\
\mu \mathrm{m}\end{array}$ & $\begin{array}{c}1.23 \pm 0.57 \\
1.30 \\
0.72-1.59\end{array}$ & $\begin{array}{c}4.38 \pm 0.83 \\
4.02 \\
3.64-5.03\end{array}$ & $\begin{array}{c}2.03 \pm 0.55 \\
2.03 \\
1.90-2.25\end{array}$ & $\begin{array}{l}\mathrm{P}_{1}-\mathrm{P}_{2} \\
\mathrm{P}_{1}-\mathrm{P}_{3} \\
\mathrm{P}_{2}-\mathrm{P}_{3}\end{array}$ \\
\hline $\begin{array}{l}\text { Fibroblasts, } \\
\text { units in } \\
\text { the field of view }\end{array}$ & $\begin{array}{c}32.94 \pm+4.6 \\
31.40 \\
31.30-36.30\end{array}$ & \begin{tabular}{|c|}
$38.92 \pm 5.82$ \\
37.10 \\
$36.80-40.60$
\end{tabular} & \begin{tabular}{|c|}
$72.98 \pm 9.85$ \\
73.30 \\
$68.30-81.90$
\end{tabular} & $\begin{array}{l}\mathrm{P}_{1}-\mathrm{P}_{2} \\
\mathrm{P}_{1}-\mathrm{P}_{3} \\
\mathrm{P}_{2}-\mathrm{P}_{3}\end{array}$ \\
\hline $\begin{array}{l}\text { Odontoblasts, } \\
\mu \mathrm{m}\end{array}$ & $\begin{array}{c}28.91 \pm 7.9 \\
32.60 \\
20.80-35.80\end{array}$ & $\begin{array}{c}31.88 \pm 7.59 \\
33.75 \\
24.90-38.50\end{array}$ & $\mid \begin{array}{c}21.92 \pm 2.73 \\
21.90 \\
19.40-24.30\end{array}$ & $\begin{array}{l}\mathrm{P}_{1}-\mathrm{P}_{3} \\
\mathrm{P}_{2}-\mathrm{P}_{3}^{3}\end{array}$ \\
\hline
\end{tabular}

IA-Intact animals; VE-Vascular endothelium

Modeling the $\mathrm{ChS}$ mode in Wistar rats was accompanied by an increase in the vascular area of the periodontium $(P=0.012)$ and pulp $(P=0.009)$, and in the thickness of the periodontal $(P<0.0001)$ and pulp $(P=0.0048)$ endothelium walls, as well as by an increase in the number of fibroblasts in the visual field $(P<0.0001)$ and a decrease in the level of odontoblasts $(P=0.0163)$, compared to intact rats.

A comparative analysis of changes in the parameters of the dentition system in rats of this line in different stress modes showed a maximum increase in the values of the vascular area of the periodontium $(P<0.001)$ and pulp $(P<0.0001)$, with a decrease in the area of the periodontal $(P<0.0001)$ and pulp $\mathrm{CT}(P<0.0001)$ in conditions of AS, compared with ChS. The endothelium of the periodontal vessels $(P<0.0001)$ and the pulp $(P<0.0001)$, as well as the odontoblast index $(P<0.001)$, showed an increase in values, while the number of fibroblasts $(P<0.0003)$ showed a decrease in AS, in relation to $\mathrm{ChS}$ data.

In our study, when implementing the AS mode in Wistar rats, an increase in primary, secondary and final LPO products was observed, which may be a natural phenomenon in conditions of stress factor exposure. In many ways, this may be due to participation of neurotransmitters of the sympathetic 
and parasympathetic parts of the autonomic nervous system in increasing the LPO intensity under stress. ${ }^{(24)}$ A likely consequence of these changes may be the development of prolonged and excessive LPO with further irreversible destructive changes in membranes and associated enzymes. ${ }^{(25)}$ Our results are consistent with a number of studies that postulate the accumulation of LPO metabolites in AS in animals after immobilization was used as a stress factor. ${ }^{(26)}$

The use of a different exposure mode (replacing a single exposure with a systematic one) in Wistar rats also led to an intensive accumulation of LPO products, in particular KD-CT and TBARs, in comparison with the pre-stress period. At the same time, we noted higher growth values of the final LPO products (TBARs), in contrast to the values registered during a single immobilization. Previously, it was shown that the mode of ChS exposure, as opposed to other types of exposure (e.g. with smaller hour intervals between effects) is characterized by a sharp decrease in resistance to acute hypoxia. ${ }^{(16)}$ It was also previously shown that this mode is characterized by more intensive activation of stress-implementing systems, which is manifested in an increase in the content of the circulating stress hormones corticosterone and epinephrine, and, accordingly, increased activity of metabolic reactions. (27) Hypermetabolism, which is necessary to ensure a new level of the body's functioning, requires mobilization of the body's energy resources, which can explain the strengthening of cascade LPO processes, accompanied by higher values of TBARs. $^{(12)}$

When evaluating changes in the AOD system in Wistar rats, we obtained multidirectional results, depending on the stress mode. Thus, under AS in animals, there was a decrease in the level of TAA, the integral indicator, with a simultaneous increase in the average values of the AOD components: the SOD activity, retinol content and GSH. It is known that when this mode is implemented, all the body's reserves are directed to actively overcome the action of an extreme stimulus. ${ }^{(15)}$ At the same time, the effectiveness of protective reserves is manifested by maximizing functions, increasing the intensity of the main exchange and catabolic processes. Increasing the activity of antioxidant factors in this case can be considered as an adaptive response aimed at leveling the LPO processes. These components can act as biological membrane stabilizers and participate in the inactivation of free radicals; accordingly, they can hinder the development of chain free-radical oxidation processes of organic compounds, primarily unsaturated tissue lipids. ${ }^{(25-29)}$

The ChS mode, in comparison with intact animals, was accompanied by similar reactions to the previous mode - a decreased TTA level, an increased SOD activity and reduced content of $\alpha$-tocopherol. The greatest number of differences in the studied components was recorded between stress modes. These differences related to low levels of $\alpha$-tocopherol, retinol, and GSSG in ChS. The antioxidant role of fat-soluble vitamins is manifested at all levels from subcellular to organism. $\alpha$-tocopherol reacts simultaneously with peroxide radicals of the main fatty acids of biomembranes and with singlet oxygen; it also inhibits amino acid radicals, protects cells and tissues from damage caused by NO-radicals, and prevents atherogenic changes in low density lipoproteins. ${ }^{(30)}$ Having conjugated DB in the molecule, retinol is able to interact with free oxygen radicals, which also makes it an effective antioxidant. ${ }^{(31)}$ As a result, we can talk about the lack of functioning of antioxidant factors when using this mode of exposure. We also registered a significant increase in the level of final TBARs in this stress mode, which, with a unidirectional decrease in AOD factors, can have an extremely negative effect.

Analysis of the characteristics of the dentition system's structural tissues in Wistar rats indicated an increase in vascular area and a decrease in the area of the periodontal CT under AS. The periodontium basis is CT with its main structural elements, collagen fibers; there are also various cellular elements (fibroblasts, osteoblasts). ${ }^{(3)}$ Based on the anatomical characteristics of the periodontium, we can conclude that in Wistar rats, when modeling the AS mode, there is an increase in the area of blood vessels, with a natural decrease in the main component-CT. A number of studies indicate the presence of numerous structural and functional disorders in periodontal tissues under stress. ${ }^{(14,32)}$ Stress factors cause blood flow disorders, cell hypoxia, and redox balance disorders. ${ }^{(33)}$

Thus, we have shown a significant increase in the concentration of final LPO products in animals under AS, which can have a direct disordering effect on periodontal composition. We also found similar changes in the vessels and CT of the rats' tooth pulp. The tooth pulp is known to be a loose $\mathrm{CT}$ that fills the tooth cavity and contains a large number of nerve endings and blood and lymph vessels. ${ }^{(3)}$ Since the morphological features of the pulp are related to its functions, we can assume the development of dysregulatory changes in this component of the dentition system under the influence of a stress factor in experimental animals. Moreover, the area of the pulp CT is significantly reduced, which indicates serious morphological disorders that lead to excessive growth of the pulp's vascular component under AS.

Another important indicator of the presence of morphofunctional disorders under the stress factors is the size of the endothelium of the periodontal and pulp vessels. In Wistar rats with $\mathrm{AS}$, there was a multiple increase in this indicator both in the periodontium and in the pulp. This can contribute to narrowing the lumen of blood vessels, reducing their hemodynamic properties and disrupting microcirculation. The cell elements that make up the periodontium and pulp are extremely diverse, represented by both sedentary and mobile cells, with the largest population of cells being fibroblasts, some of which can differentiate into stationary cell elementsfibrocytes - and the other part into myofibroblasts capable of contractile activity. ${ }^{(3,33)}$ In our study, we found an increase in the number of fibroblasts, which can be interpreted as activation of protective mechanisms due to the presence of morphological changes in tissues. The plastic function of the periodontium and pulp is also carried out due to the activity of odontoblasts, which, forming the peripheral layer, participate in the formation of dentin. The total number of odontoblasts under AS did not change and remained at the level of control (pre-stress) values.

Changing the mode of exposure to chronic caused an increase in the vascular area of periodontium and pulp with a natural decrease in the area of $\mathrm{CT}$. At the same time, there 
was a slightly reduced increase in the thickness of the vascular endothelium, against the background of a maximum increase in the number of fibroblasts and a decrease in the content of odontoblasts.

In the literature, there are data on the development of a number of morphological changes in the oral cavity in rats under conditions of chronic psychophysiological stress in the form of microcirculation disorders, local bleeding in tissues, changes in the directions of collagen fiber bundles and bundle deformation. ${ }^{(33)}$ In addition, our study registered a more pronounced imbalance in the state of LPO processes in this mode, which may further contribute to chronization of inflammatory periodontal diseases.

Thus, in Wistar rats, the processes of LPO-AOD undergo changes depending on the mode of stress exposure. Thus, when modeling AS, there is an increase in LPO reactions at the stage of primary and secondary products with simultaneous activation of antioxidant factors. The $\mathrm{ChS}$ mode is characterized by a more pronounced imbalance during nonspecific protective reactions; with insufficient reserve capacity of the antioxidant system, the ratio changes toward pro-oxidant factors. Depending on the stressor mode, the indicators of the dentition system also underwent changes with more intense morphofunctional changes in AS.

\section{Competing Interests} interests.

The authors declare that they have no competing

\section{References}

1. Zorn JV, Schür RR, Boks MP, Kahn RS, Joëls M, Vinkers $\mathrm{CH}$. Cortisol stress reactivity across psychiatric disorders: A systematic review and meta-analysis. Psychoneuroendocrinology. 2017;77:25-36. doi:10.1016/j. psyneuen.2016.11.036.

2. Kolesnikova LI, Darenskaya MA, Kolesnikov SI. [Free radical oxidation: a pathophysiologist's view]. Bulletin of Siberian Medicine. 2017;16(4):16-29. doi: 10.20538/16820363-2017-4-16-29.[Article in Russian].

3. Gaivoronskaya MG, Gaivoronsky IV. Functional and clinical anatomy of the dentition system: textbook for medical schools. Saint Petersburg: SpetsLit, 2016;128. [Textbook in Russian].

4. Meerson FZ. [Protective effects of adaptation and some prospects for the development of adaptive medicine]. Advances in Physiological Sciences. 1991;22(2):52-87. [Article in Russian].

5. Amraoui W, Adjabi N, Bououza F, Boumendjel M, Taibi F, Boumendjel A, et al. Role of Selenium and Vitamin E, Natural Antioxidants, against Bisphenol A-Induced Oxidative Stress in Wistar Albinos Rats. Toxicol Res. 2018;34(3):231239. doi:10.5487/TR.2018.34.3.231.

6. Darenskaya MA, Kolesnikov SI, Rychkova LV,

*Corresponding author: Marina A. Darenskaya, PhD, ScD. Scientific Centre for Family Health and Human Reproduction Problems, Irkutsk, the Russian Federation. E-mail: marina darenskaya@inbox.ru
Grebenkina LA, Kolesnikova LI. Oxidative stress and antioxidant defense parameters in different diseases: ethnic aspects. Free Radical Biology\&Medicine. 2018;120(S1):S60. doi: 10.1016/j.freeradbiomed.2018.04.199.

7. Ershova OA, Bairova TA, Kolesnikov SI, Kalyuzhnaya OV, Darenskaya MA, Kolesnikova LI. Oxidative Stress and Catalase Gene. Bull Exp Biol Med. 2016;161(3):400-3. doi:10.1007/s10517-016-3424-0.

8. Bairova TA, Kolesnikov SI, Kolesnikova LI, Pervushina OA, Darenskaya MA, Grebenkina LA. Lipid peroxidation and mitochondrial superoxide dismutase- 2 gene in adolescents with essential hypertension. Bull Exp Biol Med. 2015;158(2):1814. doi:10.1007/s10517-014-2717-4.

9. Singh R, Srivastava AK, Gangwa NK, Singh U, Singh R. Ameliorative Effect of Vitamin E on Cypermethrin Induced Hepatotoxicity and Oxidative Stress in Male Wistar Rats. Journal of Animal Research. 2017;7(3):445-450. doi:10.5958/2277-940X.2017.00066.3.

10. Kolesnikova LI, Rychkova LV, Kolesnikova LR, Darenskaya MA, Natyaganova LV, Grebenkina LA, et al. Coupling of Lipoperoxidation Reactions with Changes in Arterial Blood Pressure in Hypertensive ISIAH Rats under Conditions of Chronic Stress. Bull Exp Biol Med. 2018;164(6):712-715. doi: 10.1007/s10517-018-4064-3.

11. Darenskaya MA, Rychkova LV, Kolesnikov SI, Gavrilova OA, Kravtsova OV, Grebenkina LA, et al. Oxidative stress parameters in adolescent boys with exogenous-constitutional obesity. Free Radical Biology \& Medicine. 2017;112:129130. doi: 10.1016/J.FREERADBIOMED.2017.10.195.

12. Novozhilov AV, Tavrovskaya TV, Ivanov VA, Morozov VI. Hematological parameters and redox balance of rat blood in the dynamics of immobilization. Bull Exp Biol Med. $2013 ; 155(4): 447-50$.

13. Kolesnikova LI, Kolesnikov SI, Korytov LI, Suslikova MI, Darenskaya MA, Grebenkina LA, et al. Oxidative Stress as Mechanisms of Reduced Glucose Absorption under Conditions of Immobilization Stress. Bull Exp Biol Med. 2017;164(2):132-135. doi:10.1007/s10517-017-3941-5.

14. Wutzke MLS, Leite MA, Nassar CA, Nassar PO, Brancalhão RMC, Bertolini GRF, et al. Immobilization and experimental periodontitis in tibial anterior muscle of wistar rats. Journal of Pre-Clinical and Clinical Research. 2019;13(1):1-4.

15. Volchegorsky IA, Dolgushin II, Kolesnikov OL, Tseilikman VE. Experimental modeling and laboratory evaluation of body adaptive reactions. Chelyabinsk, 2000;167. [Textbook in Russian].

16. Tseilikman VE., Tseilikman OB, Sinitsky AI, Lavin EA, Lapteva IA, Gornostaeva AB, et al. [Biochemical strategies of adaptation in conditions of chronic stress]. Bulletin of SUSU. Ser. Education, Health care, Physical culture. 2008;14(4):5657. [Article in Russian].

17. Volchegorsky IA, Nalimov AG, Yarovinsky BG. [Comparison of different approaches to determining the products of lipid peroxidation in heptan-isopropanol extracts of blood]. Voprosy meditsinskoi khimii.. 1989:127-131. [Article in Russian].

18. Gavrilov VB, Gavrilova AR, Mazhul LM. [Analysis of methods for determining the products of lipid peroxidation in blood serum by the test with thiobarbituric acid]. Voprosy meditsinskoi khimii.1987;1:118-122. [Article in Russian]. 19. Klebanov GI, Babenkova IV, Teselkin YuO, Komarov OS, Vladimirov YuA. [Evaluation of the antioxidant activity of 
blood plasma using yolk lipoproteins]. Laboratornaya rabota. 1988;5:59-62. [Article in Russian].

20. Chernyauskene RCh, Varshkevichene ZZ, Grybauskas PS. [Simultaneous determination of vitamin $\mathrm{E}$ and $\mathrm{A}$ concentrations in blood serum]. Laboratornaya rabota. 1984;6:362-365. [Article in Russian].

21. Misra HP, Fridovich I. The role of superoxide anion in the autoxidation of epinephrine and a simple assay for superoxide dismutase. J Biol Chem. 1972;247(10):3170-5.

22. Hisin PJ, Hilf R. Fluorometric method for determination of oxidized and reduced glutathione in tissues. Anal Biochem. 1976;74:214-26.

23. Manual on Experimental (Preclinical) Study of New Pharmacological Substances. Ed. R. U. Khabriev. Moscow, 2005. [in Russian].

24. El-Dein B, Mohamed I, Mohamed FA, Ahmed MA, Soliman NBED, Lasheen NN, et al. Sex Differences in Metabolic Responses to Chronic Immobilization Stress in Rats. Bulletin of Egyptian Society for Physiological Sciences. 2020;40(1):148-165. doi:10.21608/besps.2019.18674.1036.

25. Sies H. Oxidative stress: a concept in redox biology and medicine. Redox Biol. 2015;4:180-3. doi: 10.1016/j. redox.2015.01.002.

26. Solin AV, Lyashev AY, Lyashev YD. Effects of Opioid Peptides on Changes in Lipid Metabolism in Rats Subjected to Swimming Stress. Bull Exp Biol Med. 2017;16293):313-315. doi:10.1007/s10517-017-3603-7.

27. Tseilikman VE, Kozochkin DA, Sinitsky AI, Tseilikman OB, Lapshin MS, Kuzina OV, et al. Effect of Repeated 1-h Episodes of Immobilization Stress on Activity of Glucocorticoid
Metabolism Enzymes in the Liver. Bull Exp Biol Med. 2015;160(5):614-6. doi: 10.1007/s10517-016-3230-8.

28. Kolesnikova LI, Darenskaya MA, Grebenkina LA, Dolgikh MI, Astakhova TA, Semenova NV. Gender differences in parameters of lipid metabolism and of level of antioxidants in groups of juveniles-the Even and the Europeans. Journal of Evolutionary Biochemistry and Physiology. 2014;50(1):3441. doi: 10.1134/S0022093014010058.

29. KolesnikovaLI,DarenskayaMA, SemenovaNV, Grebenkina LA, Suturina LV, Dolgikh MI, et.al. Lipid peroxidation and antioxidant protection in girls with type 1 diabetes mellitus during reproductive system development. Medicina (Kaunas). 2015;51(2):107-11. doi: 10.1016/j.medici.2015.01.009.

30. Atkinson J, Harroun T, Wassall SR, Stillwell W, Katsaras J. The location and behavior of alpha-tocopherol in membranes. Mol Nutr Food Res. 2010;54(5):641-51. doi: 10.1002/ mnfr.200900439.

31. Pisoschi AM, Pop PA. The role of antioxidants in the chemistry of oxidative stress: A review. Eur J Med Chem. 2015;97(5):55-74. doi: 10.1016/j.ejmech.2015.04.040.

32. Sarapultsev AP, Sarapultseva MV, Medvedeva SYu, Mukhlinina EA, Danilova IG. [Assessment of stress response and mucosal damage in violation of the anesthetics administering technique]. Parodontologiia. 2013;18(2):29-33. [Article in Russian].

33. Antonova IN. Changes in the Masticatory Muscles, Periodontal Tissues and the Pharyngeal Ring in Wistar Rats in Chronic Psychophysical Stress. Neuroscience and Behavioral Physiology. 2008;38(9):891-895. doi: 10.1007/s11055-0089068-4. 